\title{
Infusing African management philosophy into project management
}

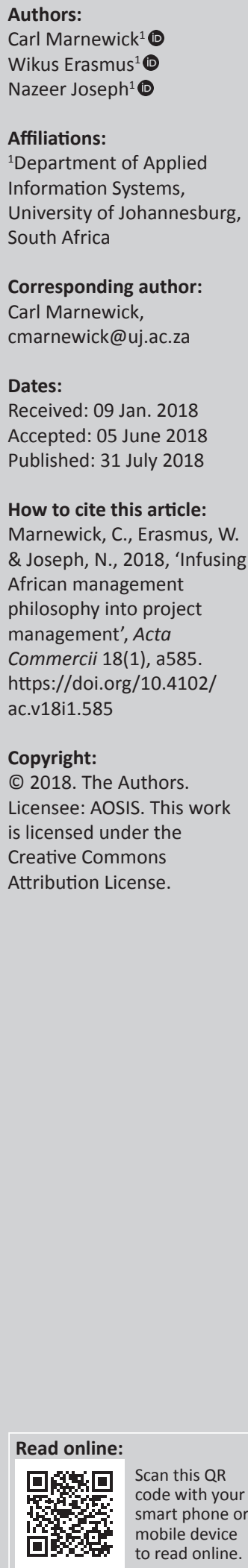

Orientation: The project management field of study is investigated in the context of the current debate on decolonisation of the university curriculum.

Research purpose: Current project management theories and curriculum are based on Western management philosophy (WMP). This creates tension on the African continent where the debate is currently about the revival of African management philosophy (AMP) and how it should form part of management theories and the discourse in general.

Motivation for the study: The problem currently is that AMP is not incorporated or even discussed within project management literature. The aim of this article is to create discussion around AMP and how it can be infused into project management theories and ultimately the curriculum. The AMP and WMP are discussed through the lens of project management, specifically the Project Management Body of Knowledge.

Research design, approach and method: Philosophical discussion was employed to facilitate the discussion of infusing AMP into project management. Various historical concepts and practices were explored to provide perspective concerning management philosophies and theories.

Main findings: Infusing AMP into the curriculum must be a conscientious effort from the academic staff who teach project management. Moreover, true infusion of AMP is best facilitated through the interaction between academics, students and stakeholders. There are, however, certain processes that are principle agnostic and are independent of either AMP or WMP.

Practical/managerial implications: We should philosophise more on infusing AMP into project management, creating new theories, and that the curriculum should be adjusted to incorporate AMP.

Contribution/value-add: This paper stimulates discussion around AMP and project management.

\section{Introduction}

The social media movement in South Africa called \#FeesMustFall reintroduced the concept of decolonisation to all universities' agenda (Hamilton 2016). Decolonisation was but one of several demands that students brought to the fore during the \#FeesMustFall campaign. Other demands included the abolishment of Afrikaans as tuition language as well as free higher education.

Decolonisation is a concept that academics have been struggling with since the concept was introduced (Heleta 2016; Mudimbe 1985). Various problems have arisen, for example what needs to be decolonised, to what extent should decolonisation occur and which academic fields can be decolonised (CHE 2017; Wingfield 2017). The debate is still wide open as to what decolonisation implies for higher education institutions (HEIs) and what should and needs to be done to redress the wrongs of the past (Heleta 2016; Maserumule 2015). The current debate on decolonisation is at a very high level but it has not filtered down to specific disciplines. It has not been introduced in the project management discipline. This article explores the notion of decolonisation within this discipline and seeks to introduce decolonisation as an agenda point. Academic staff within the project management discipline still struggle with this concept and with the extent to which the curriculum must change to accommodate decolonisation. Literature on decolonisation focuses either on decolonisation as a concept or on the humanities (Pillay 2015; Tuck \& Yang 2012). This narrow focus creates a challenge for academic staff within the project management discipline as they do not have any theory to draw upon. The purpose of this article is to start the debate within 
the project management discipline and create theories and concepts that can be used as a stepping stone.

The lack of research on the role that African management philosophy (AMP) can play within the project management discipline creates an opportunity for scholars. At present, project management and the philosophies around it are informed by Western management philosophy (WMP). Western management philosophy in project management is evident in formal standards and practices such as Project Management Body of Knowledge (PMBOK), Association for Project Management Body of Knowledge (APMBOK) and PRojects IN Controlled Environments 2 (PRINCE2) (Association for Project Management 2012; Office of Government Commerce 2009; Project Management Institute 2013). This raises the question whether African and for that matter other non-Western philosophies can be introduced into the project management discipline. It also raises the question whether AMP has been subconsciously applied in the management of projects. This article takes a philosophical approach to the problems raised and seeks to understand how AMP can be incorporated into project management. The focus is not to replace WMP, but to determine how African and Western philosophies can be infused into project management. Project managers can draw from a wealth of knowledge when these two seemingly contradicting management philosophies are infused into each other.

\section{Literature review}

Before attempting to answer the question of what decolonisation constitutes, it may be worthwhile to first consider what colonisation entails. To colonise, by definition, means to take control of an area and send people to live in that area (Webster 2016). Another view is that settlers were sent to establish political control over a territory by controlling the indigenous population and thereby appropriating the said territory (Stevenson 2010).

\section{The history of colonisation}

The standard definition of colonisation refers to political and geographical colonisation. Many territories have been colonised over the last seven centuries by the so-called stronger nations. The first Western powers to do so in the modern age were Portugal and Spain (Lilly 2008; Newitt 1986) during the 1400s. These two empires focused mostly on colonising North and South America, while Portugal also established settlements on the western and Mediterranean coasts of Africa during exploratory excursions. The primary motivation for this exploration was the desire of these nations to benefit from the lucrative spice trade at the time (Bailey 2007). As such, colonies were established on these routes as resupply points to further extend reach.

When these supply points became too costly to protect against other nations, the Dutch and the British took control of many of these proto-colonies, often by force (Da Silva 2011; Leonard 2005; Parsons 2004; Porter \& Louis 2001). With the discovery of minerals on African soil, the so-called Scramble for Africa began, which motivated many European powers to actively settle in territories that were not formally governed by indigenous populations (Pakenham 2015). These colonising nations included the British Empire, The Netherlands, France, Germany, Italy and Portugal.

The British Empire expanded towards the Americas during the early 1600s and established the original 13 colonies of the region on the east coast (Middleton \& Lombard 2011). Various indigenous people were displaced during this period as the colonies grew. The British Empire prolifically colonised territories far from its own borders, most notably Australia and probably most controversially the Falkland Islands.

Japan also colonised surrounding regions during the 1800s and 1900s (Myers et al. 1984). Japanese Korea and various islands surrounding Japan, Indonesia, Cambodia, Taiwan and large areas of China were colonised by Japan. These areas are traditionally viewed as being under Japan's control at some point in the past. Japan was motivated to reassert its dominance in the area by taking these territories under its control once again as a matter of national pride.

Russian expansionism during the mid-20th century created various multi-ethnic societies when Soviet citizens relocated to new territories after the Second World War (Huntington 2000). This expansionist policy also manifested in Africa. The result was that threatened European nations showed a renewed interest in the presence in Africa as a measure to curb Soviet expansion and to create distance or buffers between the territories controlled by these competing nations.

Colonisation has also occurred in the Middle Eastern and Balkan regions by way of various empires that conquered neighbouring states. Most notable of these was the Ottoman Empire, which was established in 1452 based on an expansionist policy fuelled by national pride. This empire was dissolved in 1922 after its defeat in the First World War.

It seems that during the vast history of colonisation, the main motivations for taking political control of other territories were (1) seeking more resources, (2) expanding territory, (3) national pride and (4) creating buffer regions between competing nations.

\section{Impact of colonisation}

The penetration of foreign settlers in new territories had a profound effect on the indigenous population of those regions. Many of these effects negatively affected the indigenous populations (Bernhard, Reenock \& Nordstrom 2004; Jiggins 1989; Turshen 1977).

One of the greatest negative impacts of colonisation on indigenous populations was the establishment of slave trading from these new territories. Most, if not all, of the 
colonising nations engaged in slave trading during their stay in Africa as well as in the Americas (Conniff \& Davis 2004; Lovejoy 2011; Nunn 2008). These nations include the major European powers, such as Portugal and the British Empire, as well as Middle Eastern nations and traders. Slavery was an economic activity that sought to increase economies of scale by acquiring inexpensive labour and treating it as a resource (Berry 1989). Removing entire groups of indigenous populations from an area left a vacuum that the remaining indigenous population could not fill and they became more exploitable as a group.

Another impact of colonisation is the assimilation of culture. Indigenous populations came into contact with colonising foreigners. Where such contact occurs, different groups start trading and communicating. The dominant or stronger group may force the weaker culture to adapt to their ways of living (Ting-Toomey et al. 2000). Examples are Eastern European people who were forced to adapt to living in villages by Russian colonialists even though their culture was to live in isolated wild areas (Poirier \& Ostergren 2002).

An instrument many colonial nations used to force indigenous cultures to become more accepting of the foreign power was religion (Chidester 1996; Daughton 2006; Henn 2014). Although many missionaries visited and settled in these faroff places with altruistic motives, the effect was that indigenous populations in some cases gave up some central ideas of their identities. Through adopting the religion of the colonising nations, the indigenous populations could now more easily identify with settlers and in some cases could be less resistant to being politically controlled by the stronger power.

Prior to colonising, there were different or ill-defined borders and territorial boundaries (Mignolo 2012). This was primarily because of the indigenous populations having agreements with the tribes or other people neighbouring them or because of geographic landmarks. Colonising nations had little knowledge of these conventions or agreements and proceeded to mark out boundaries that made sense to them, often without regard for where and how the indigenous populations had been living. The effect was that certain populations were divided by new borders and the indigenous populations developed separately from one another. An example of this is the Tswana people of Southern Africa where one group resides in northern South Africa and another within the borders of Botswana (Comaroff 2013).

With the arrival of foreign colonisers to a region, new knowledge and technology were imported as well. This knowledge was used by settlers primarily to develop their new surroundings to achieve the level of civilisation that they were accustomed to in their home countries. As a consequence, indigenous populations did not immediately benefit from new innovations. However, trade was an activity that was almost immediately practised between settlers and indigenous populations (Smith 1999). This activity had an immediate positive impact on the economy of the indigenous populations as the settlers had a massive demand for local resources, not having the time to initially raise livestock and crops while establishing infrastructure. As the economy and the infrastructure of the settlers became established and stable, the dependence on indigenous populations' resources lessened and an opportunity for economic exploitation arose (Grier 1999). This was also fuelled by the greater political control that settlers achieved over indigenous populations.

Increased levels of trade provided indigenous populations with access to new technologies and products. One significant example of this is the introduction of maize and the cultivation technology to the African continent by Portuguese settlers and explorers during the 1500s (Jeffreys 1953; Miracle 1965). This access to new products, technologies and knowledge benefitted the indigenous populations by increasing their food-producing capabilities and allowing them to innovate in their own context. Another example is the introduction of new and better hygiene practices in certain colonised territories, for example in Tanzania by the British Empire (Bashford 2003; Eckert 2004). It must also be noted that in some instances, settling nations brought with them health hazards that the indigenous populations had never had to deal with before. One of the most cited examples is the 'Columbian Exchange' in which the Spanish settlers introduced smallpox to the local inhabitants of the Americas where this disease had not existed before (Nunn \& Qian 2010).

Codified legal systems were often introduced by settlers in their new territories where some form of legal system already existed (Joireman 2001). In South Africa, Dutch-Roman law supplanted the original tribal 'law of the land'. All matters in the territory were dealt with according to this basis, regardless of indigenous or customary law.

In summary, it can be said that populations in colonised regions lost their independence and in many cases were exploited for economic reasons. This took place through the export of resources that included people as chattels and slaves. The act of colonisation also increased opportunities for indigenous populations to become involved in economic trade and gain access to new technologies, infrastructure and ideas that undoubtedly also had some sort of positive effect. These aspects disproportionately benefitted the settlers rather than the indigenous populations.

It is, however, after the decolonisation of territories that the economic and developmental benefits became more tangible and accessible to indigenous populations as they 'inherited' them. The original inhabitants gained their independence again when colonial powers returned political control. The established and developed infrastructure and economy then came under the direct control of the indigenous populations for their direct benefit after they were often excluded from participating in economic and political activities. 


\section{A brief history of decolonisation}

In 1960, the United Nations (UN) General Assembly adopted Resolution 1514 (XV) as the Declaration on the Granting of Independence to Colonial Countries and Peoples (United Nations General Assembly \& United Nations Office of Public Information 1974). This resolution required all member states to recognise that subjugation and exploitation by a foreign nation is a denial of basic human rights as enshrined in the UN founding documents. It also required taking steps to grant all regions held in trust or as non-self-governing territories their independence.

As a result, 80 former colonies or such territories gained their independence from countries such as France, Britain, USA, Japan and South Africa. Seventeen non-self-governing territories remained as of 2016. These are mostly smaller islands in the Atlantic, Pacific and Caribbean regions held predominantly by the United Kingdom and less so by the USA, France and New Zealand. The inhabitants of some of these regions have openly declared their support for the colonial powers of their territory and have rejected independence (Dunleavy 2014). It can then be said that these populations have not exercised their right to selfdetermination (Dunnett 1983).

Various economies thrived after independence was gained, most notably India and the USA (Malhotra 2014; Walton \& Rockoff 2013). This is mainly because of the fact that the resources that were exported to colonising nations now came under the control of indigenous populations or settlers who are considered a bona fide part of that particular region.

After the independence of a region, the people that came into power, most often the original inhabitants or colonialised populations, had to decide what was to be done with their 'inheritance'. Administrative and legal systems that were set up under colonial rule had become the norm (Wolfe \& Mikdashi 2013). These systems were essential for a smooth transition to a new dispensation where the descendants of the original inhabitants took political and administrative control of public institutions. However, where commerce thrived prior to independence, private organisations remained in the hands of citizens who had colonial forefathers. As all citizens in a democratic country have property rights, these economic benefits cannot simply be expropriated by force or litigation (Griffiths 2013). Inevitably, many of the cultural institutions that were imported also remained part of life once independence of a territory was granted. Many of the descendants of the colonisers remained in their adopted country and carried on living as they had under colonial rule. This facilitated a continued blending of culture in certain spheres of public life and would nevertheless require all the diverse populations in a territory to cooperate.

The historic term for colonisation related exclusively to increasing geographical areas for political and economic gain. Other reasons for colonisation also included creating buffer zones between competing nations. Decolonisation occurred as a result of the recognition of the individual human right to self-determination as well as the movement for decolonialism prior to this recognition by the UN. The impact of colonisation was varied and mostly resulted in the disenfranchisement of indigenous populations at the cost of their way of life. It is undisputable that colonisation had a detrimental effect on indigenous populations during the process of colonisation and after independence.

The cultural impact of colonisation was not as quick to dissipate; the culture of previously colonised populations and settlers mingled as they had to coexist. The so-called colonisation of the mind is a subject for robust debate, but what can be said is that perhaps the following principles may apply:

- All humans have a right to self-determination and independence.

- There is an acknowledgment of cultural diversity and a willingness to coexist with it.

- Intellectual diversity may exist because of how the world is perceived by diverse people.

- Transferral of ideas, as in education, should be available in a manner to those who seek it.

- Knowledge may be more relevant and valuable to the context in which it was created.

- Established knowledge can and should be supplanted by knowledge that is proven to fit reality better.

A more serious type of colonisation is considered in the next section, that is, the colonisation of one's mind and thoughts.

\section{The concept of intellectual decolonisation}

The Oxford English Dictionary defines 'decolonisation' as the act of withdrawal from a country by another country after it was colonised. Examples are the withdrawal of France from the Democratic Republic of Congo or the withdrawal of England from South Africa. This implies that the previously colonised countries will have political and economic freedom after decolonisation. From an academic perspective, decolonisation has a totally different meaning. It focuses on intellectual views and the liberation of the mind from the ideas that the colonised country and its indigenous people are inferior.

Pillay (2015) has very extreme views in this regard and mentions three types of violence. Decolonisation was achieved in most instances through the use of political and economic violence. Intellectual decolonisation can only be achieved through the use of epistemic violence. Epistemic violence is about thought (Pillay 2015). The argument is that as universities and other HEIs are at the heart of knowledge and knowledge creation, epistemic violence or intellectual decolonisation should also take place at universities. This notion of intellectual decolonisation is also raised by Hunter (2012). He is of the opinion that no previously colonised country can be totally free or independent until it 'espouses, teaches, and promotes its own indigenous ideas and values' (Hunter 2012:1). He believes that previously colonised 
countries are still trapped within the syndrome of intellectual colonisation.

Some have argued that even the very action of thinking has been colonised and needs to be decolonised for the benefit of indigenous people (Kaunda 2016; Thiong'o 1994; Todd 2016). This debate is often marked by reactionary anti-colonial statements and sentiments. This is especially the case with regard to language where it is theorised that language and culture are inexorably linked. Thus, the enforcement of one language on indigenous people, to whom it is a foreign language, colonised their mind in that their histories and values were translated into another context and reintroduced to them again.

This then is linked to education. Academics in the educational sciences believe that education, at least primary education, yields the best results if students receive it in their home language (Heugh 2015b; Mackenzie 2013). However, schools and universities are usually public institutions that need to cater for the greatest number of stakeholders. These diverse environments would struggle to provide home languagebased education to every single cultural group (Heugh 2015a; Kwong et al. 2014). These groups who acquire knowledge will apply it, at least initially, in their immediate environment. Therefore, the ideas that are acquired will be of more value if they are closely relatable and applicable to the current environment. It could be said that Afro-centric knowledge may not be strongly applicable in North American contexts, nor may Western European knowledge be directly applicable in African contexts.

While many indigenous groups are admirably making strides to reclaim and protect their culture, it would again be obtuse to ignore the fact that not all people are always proficient in each other's language. Therefore, falling back on the language most often spoken in a particular region or a language that allows communication on the global stage is preferable as it accommodates the greatest number of individuals. It therefore becomes clear that education needs to be of benefit to all those who wish to become educated. Higgs (2012) argues that educational discourse in Africa requires a philosophical framework that:

- Respects diversity: diversity in many cases serves as an opportunity to learn from others and be exposed to new ideas (Flood \& Romm 1996). These new perspectives and ideas can serve to enhance the value created by an organisation (Avery et al. 2013; Cook 2016). However, just because an organisation or a country has recognised the fact that diversity exists does not mean that diversity is respected (Erasmus 2008). Respecting diversity may mean that we have a deep admiration for another's cultural differences or merely a level of regard (Stevenson 2010). At the very least, this requires a willingness to coexist with people who have different ideas and opinions other than yourself. This principle should be applicable to all parties involved.
- Acknowledges individual lived experiences: acknowledging another's lived experiences requires us to be open to questioning our own interpretation of the outside world (Merryfield 2000). Personal experiences may be interpreted subjectively. We may move closer to an objective view of the world or a particular experience when compared to another individual's interpretation. An objective view of the world is more representative of facts and less influenced by emotions. While acknowledging an individual's lived experience, we cannot divorce this from reality. When the opinion derived from a lived experience is incongruent with reality, that opinion cannot be considered valid.

- Challenges the dominance of established knowledge: no article of knowledge or results thereof should be considered unassailable (McComas 2004). Science, in all its disciplines, has a self-correcting nature. As new knowledge is uncovered, and theories more congruent with reality are developed, older theories and established facts become less supportive of reality. Therefore, the dominance of established knowledge is not sacrosanct. However, challenging established knowledge without a strong basis is futile. Calls have been made to reboot science completely and start right from the beginning (Henderson 2016). However, this extreme measure will require a scientific approach to come to the conclusion that science must be scrapped. This is an incoherent argument and begs the following question: how will knowledge then be gained again? Although science is considered a neutral concept, the epistemology and ontology of science for colonised nations would have to be called into question. Science can be abused by individuals with bias and their own personal agendas (Ioannidis 2012). It is this kind of result from science that can be challenged.

The problem with the current curriculum at universities is that the focus is still on Western philosophies. This is irrespective of the discipline. Hunter (2012) deduces that preference is given to Western ideas and the so-called gurus even when these ideas are not directly suited to the different contexts and varied business situations within the local environment. The adoption of Western business literature poses two concerns. The first concern is that this literature is focused on a post-industrial economy, whereas most colonised countries have a developing economy. The second concern is that Western business literature is based on the premises of a Western secondary school system, which is very different in content and method from schools in a colonised country or region (Hunter 2012). A specific example is that $60 \%$ of Grade 4 learners in South Africa do not comprehend what they are reading (Janse van Rensburg 2016). This is because English (the language of the coloniser) is used as the language of teaching and learning in South Africa. Ramoupi (2015) is of the opinion that learners and students are expected to leave their strengths, that is, their languages and cultures, at the entrances to their schools and 
universities. These strengths can only be collected on their way out after school and lectures.

Eastern and African philosophies such as Confucianism and ubuntu (Broodryk 2002) are not integrated into the decolonised curriculum. South African universities have contributed little over the last 20 years to ensure a substantial paradigm shift in teaching, learning and researching to contribute meaningfully to the decolonisation of the curriculum and its content (Ramoupi 2015). This raises the question of how intellectual decolonisation should take place. Pillay (2015) is of the opinion that renaming buildings and statues and adding a new African course to a degree contribute to intellectual decolonisation, but that more is needed. The solution is to place Africa and it philosophies at the centre of intellectual decolonisation (Guruba 2015). Such a curriculum determines the academic formation of a new generation of scholars and academics. It assists in creating people who think in a particular way about particular subjects and talk about them in a particular language and idiom (Guruba 2015).

South African universities should not reinvent the wheel in their pursuit of intellectual decolonisation. These institutions can learn from the struggles of indigenous scholars from former colonies (McLaughlin \& Whatman 2011). Universities should not shy away from intellectual decolonisation even if it implies tension between traditional Western philosophies and African philosophies. Intellectual decolonisation should be regarded as 'an uncomfortable, power-shifting and transformational necessity for personal and professional practice' (McLaughlin \& Whatman 2011:366). Intellectual decolonisation involves a sense of recognition of and challenge to colonial forms of knowledge, pedagogical strategies and research methodologies. It contributes to the intellectual sovereignty of indigenous people (McLaughlin \& Whatman 2011).

Management philosophies, and especially research within the management discipline, have made significant strides in globalising their reach and being more inclusive of organisations in non-Western developing economies in the last two decades (Zoogah, Peng \& Woldu 2015). In contrast, Africa has remained off the radar of researchers in the field of management and, in particular, project management (Jackson 2004). This lack of research opens the door for intellectual decolonisation with regard to the management discipline. The management discipline within the African context is influenced in two ways: firstly, by a modern system originating in the colonial state (Western context) and, secondly, by a customary system rooted in ethnic level (traditional context) (Zoogah et al. 2015).

In the next section, the roots of project management are investigated and some of the greatest projects since the dawn of humankind are highlighted. The rationale is to determine which nations have applied the principles of project management and where these projects were implemented.

\section{The history of project management}

Project management has a long history prior to being formally standardised over the past 30 years. This history cannot be ignored as it provides an excellent learning opportunity for understanding how projects were constructed centuries ago. Furthermore, history can illuminate how colonisation has played a role in the development of project management. The following sections provide insights into renowned buildings from as far back as before the Common Era (BCE) and how project management was applied to realise goals.

\section{The Great Pyramid of Giza (2550-2530 BCE)}

The Egyptians established themselves as the first and greatest nation in 3200 BCE. They believed death was the beginning of a journey to the next life and embarked on a project to build the Great Pyramid of Giza to entomb Pharaoh Khufu (Edwards 2003). Although the project was conducted many centuries ago, it followed the project life cycle phases known today (Kozak-Holland 2011):

- Initiating: Architect Hemienu was tasked with designing the pyramid to entomb Pharaoh Khufu (Kozak-Holland 2011). Many pyramids were built prior to the Great Pyramid of Giza and all the instructions, designs and formulae were documented in the Book of Foundations of Temples. The book served as an instrumental part of the subsequent planning phase.

- Planning: Pharaoh Khufu was 40 years old when the project was initiated, which did not leave much time for construction. Hemienu and the overseers of quarries and transport assisted with the selection of the construction site as the site had to accommodate the specifications of the pyramid. The Giza plateau was selected as the construction site because it was a quarry itself and there was a nearby harbour to manage large volumes of resources. The work breakdown structure of the project included site preparation, construction, removal and ramp demolition. The workforce comprised 20000 workers. They were split into many groups to enable efficiency and easy monitoring.

- Executing: Three key challenges influenced the scope and schedule. Firstly, a perfectly level base had to be created. A thin perimeter trench was dug and filled with water. Workers cut out 2-ton blocks and used these to create a level plane. Secondly, 43 large granite blocks were required for the burial chamber. These were delivered from the southern region of Aswan after 10 years. The roof required 9 blocks to be moved with precision to a height of $42 \mathrm{~m}$. Thirdly, ramps were required to move the blocks. A multitude of internal ramps of $4.6 \mathrm{~m}$ were snaked within the inner structure. These were used in conjunction with an external ramp of $61 \mathrm{~m}$ to move the blocks inside.

- Monitoring and controlling: Hemienu was concerned about the burial chamber as limestone blocks were stacked above it. Stonemasons were tasked to chisel a tunnel through the limestone so that Hemienu could assess the chamber. Small cracks were noticed and were 
subsequently plastered and monitored for further changes.

- Closing: The project was completed within the allocated schedule of 20 years, which was a major feat given the time period. Furthermore, resources were used efficiently within the project's budget. Extensive planning ensured that the limited workforce was organised effectively to construct the project within time, cost and scope. The pyramid is the last surviving of the seven wonders of the world. It remained the tallest building until the construction of the Eiffel Tower in 1870.

\section{The Colosseum (70-80 AD)}

Emperor Flavian Vespasian had to restore confidence within the Roman Empire and purge the memory of tyrannical Nero. Gladiator events were previously held in temporary structures and the Colosseum Project aimed to create a permanent structure for gladiator events for the Roman people (Matthew 2013):

- Initiating: The project was pursued primarily as a political endeavour. The purpose was to show governmental generosity and give back to the people (Kozak-Holland 2011). The Emperor's regime was unstable and close to ruin as the Roman systems were on the verge of collapse. The stadium had to accommodate 50000 spectators within a short delivery period.

- Planning: Four contractors were used to deliver the project. Architectural principles developed during the construction of amphitheatres were used and applied when designing the Colosseum. Extensive equipment was required for construction such as capstans, windlasses, grins, cranes, sleds and wagons. Certain equipment had to be fabricated onsite as this would be more effective than shipping equipment to site. The workforce consisted of trade unions (guilds), soldiers and slaves. The guilds included highly skilled individuals. The workforce was approximately 20 000-30 000 men. The project required 778325 labour days. The Colosseum was built on three levels and incorporated 240 arches.

- Executing: A drainage system was initially constructed prior to building a $14 \mathrm{~m}$ foundation. Excavation was performed using ox and cart, which could each handle half a ton. The site was divided into four areas as it was not large enough for the entire workforce. Independent teams worked concurrently to promote efficient productivity. External walls used travertine, which was easily mined and hardened when exposed to air. Travertine was bonded using 300 tons of iron clamps, and not mortar like previous projects. Vaulted arches were used because they are stronger than flat ceilings. Stairs and seats were standardised and interchangeable and were installed two levels at a time to promote efficiency. A retractable roof covered the stadium and was built using the principles of mast and sails.

- Monitoring and controlling: Throughout the project, various modifications and improvements were made to the original plan and design. The top of the building went through many iterations, hence the different styling in the interior. The styling evolved over time and through the reign of three emperors.

- Closing: The project took 10 years to complete and was overall a success for the empire and the people. The flooring was strong enough for lifts to bring animals up from the dens for more intense gladiator fights. Aqueducts provided water for naval flights. Spectators were covered by the retractable roof. Drinking fountains and toilets were installed around the stadium and integrated into the water and drainage system.

\section{The Cathedral at Hagia Sophia (532-537 AD)}

In 532 significant civil unrest and riots took place in Constantinople. The riots were extremely violent and many fires destroyed sections of the city. One casualty of the fires was the Church of the Holy Wisdom (Hagia Sophia). This afforded the opportunity to construct a new extravagant church for the people (Charles 1930):

- Initiating: Emperor Justinian mandated the construction of the Cathedral at Hagia Sophia and served as the main stakeholder. The goal was to have a showpiece within the city that would outshine previous cathedrals (KozakHolland 2011). The emperor was ready to fully exploit his empire to deliver this cathedral. He made it clear that money was no object and artisans were assembled from around the world.

- Planning: The emperor took full control of project funding and construction supervision. The project was to be completed in 5 years and within the reign of Justinian. Experienced architects were required and two famous individuals were selected: Anthemius of Tralles and Isidorus of Miletus. Both architects were the equivalent of modern-day academic professors. The cathedral was to be built on a hilltop so that it would act as a watchtower for Constantinople. The area of the building would be $5250 \mathrm{~m}^{2}$ and $55 \mathrm{~m}$ high. Justinian wanted the architects to design a dome which had never been seen before. This subsequently required the architects to apply highly sophisticated geometry to engineer the dome.

- Executing: The entire interior was built using bricks and marble. The intention was to allow extensive light into the building which could reflect off the marble and thoroughly illuminate the interior. Justinian ordered the plundering of ancient temples for their extravagant columns as this would add to the cathedral and his legacy. Pumice stone and Rhodian bricks were used during the construction because they were lightweight. This, however, increased the cost as these bricks had to be shipped rather than manufactured near the site. Earthquake-resistant cement was invented and used during the project as it could handle earthquakes of 7.5 on the Richter scale. A 31 m diameter dome was created to cover and cap the cathedral. The dome was supported by four marble columns and a new, innovative design was applied to withstand horizontal forces.

- Monitoring and controlling: The two architects were given authority to direct the project at any given time. They both supervised master builders to ensure that the 
work was executed correctly. Adjustments had to be made to the original plans as the weight of the dome was too much for the square base. A rectangular base was subsequently used and the circular dome was changed to an elliptical dome.

- Closing: The project was completed in 5 years, from February 532 AD to December 537 AD. The overall cost was 2000 pounds of gold, which equates to approximately US\$3 billion today. The fast pace of the project is visible today as there are many marble pieces that overlap and do not fit correctly. A key design feature of the cathedral is that the dome has a floating effect above the plethora of windows. The ambitious goal of Emperor Justinian was realised as the cathedral stood as the tallest in the world until 1920 AD. Many churches after Hagia Sophia applied the same dome architecture and the cathedral is considered a prototype for dome design.

\section{Taj Mahal (1631-1648 AD)}

A crown palace for the fifth great Mughal Emperor Shah Jahan was to be built as a tomb upon his death (Ahuja \& Rajani 2016). Similar to the Egyptians, the belief was that there was a journey after death and these grand tombs would facilitate the transition to the afterlife:

- Initiating: The purpose was to build a mausoleum for Shah Jahan when he died (Kozak-Holland 2011). The mausoleum also had to be built within his lifetime. The Taj Mahal was thus built for the same purpose as the Great Pyramid of Giza. The mausoleum would also serve as a memorial for Shah Jahan's wife, Mumtaz Mahal. She would have her remains buried in the mausoleum upon completion. Previous architectural principles and designs from the Persians and earlier Mughals were to be used for the mausoleum.

- Planning: The mausoleum required very experienced and skilled individuals. This culminated in a team of 37 designers and architects. The emperor was actively involved in selecting the architectural design as he wanted the mausoleum to be truly unique. The principal architect was Ismail Khan who worked for the Turkish Ottomans. Finances and administration of daily duties were handled by reputable Persians: Mukrimat Khan and Mir Abdul Karim. Master masons supervised masonry and a goldsmith was tasked to cast the gold which caps the dome. The workforce required 20000 men from Persia, France, Iran, Italy and Turkey. The project made use of three stone types: common stones, semi-precious and rare, scarce stones. The mausoleum faced similar challenges to the Great Pyramid of Giza: site preparation, brick production, quarry operations, logistics, workforce accommodation and ramp construction and removal.

- Executing: Construction of the mausoleum began in 1631AD. The construction took the following sequence: The plinth and tomb construction, the Taj Gateway and garden construction, and the outstanding sections were built in phases. The foundation was built by resting each supporting beam on deep rubble and concrete holes which were connected by arches. The building has not shifted in over 385 years, which is testament to this technique. Concentric circles were applied to the double dome and were $2 \mathrm{~m}$ thick. Moreover, no pillars were used to support the double dome structure of $50 \mathrm{~m}$ high and 13000 tons. The outer Minarets were tiled outwards so that they fell away from the main building in the event of an earthquake. An animal-powered water system was developed to deliver water to the main building.

- Monitoring and controlling: Flooding from the nearby river was a concern during construction. Wells were subsequently dug so that any excess water would be absorbed before affecting the foundation. Large marble blocks and materials required precise placement in the structure. This was achieved and managed via the construction of a $15 \mathrm{~km}$ tamped-earth ramp from Agra to the site.

- Closing: Construction of the plinth and tomb took 12 years to complete. The Taj Gateway took another 10 years to complete. The Gateway signifies the divide between the material and spiritual worlds. The Taj garden (Charbagh), which is known for its beauty, spans 90000 $\mathrm{m}^{2}$ and exemplifies the overall mausoleum. The project took 17 years overall and was completed within the lifetime of Emperor Shah Jahan. The approximate cost is equivalent to 32 million rupees today.

\section{The Empire State Building (1929-1931 AD)}

The 1920s saw a race for the tallest building in New York, as many buildings aimed to achieve the world record for the tallest building in the world (Wigoder 2002). The investors of the Empire State Building wanted it to be the tallest building ahead of the Bank of Manhattan and Chrysler buildings (Kozak-Holland 2011):

- Initiating: A tender was put out for construction companies to compete. Two companies responded. Initially, Eken, the leading skyscraper constructors, proposed that they would use existing equipment and rent anything else which was required. Alternatively, the Starrett Brothers proposed that this project was unique and required the design and purchase of new, custom equipment. They noted that the equipment could be resold upon completion and would cost less than renting.

- Planning: The initial schedule was for the project to be completed in 18 months. There were many risks with building in the heart of Manhattan. Firstly, there was a possibility of serious accidents with the use and movement of heavy equipment. Secondly, 12-h traffic would make it difficult to transport equipment and supplies to the project site. The contractors determined that about 60 different skill trades were required for the project and that certain supplies would be manufactured within close proximity of the site. This project was one of the first to use Gantt charts for activities and resource allocation. The project also was the first to start construction prior to the final designs being completed. This was known as 'fast-track' construction. The aim was to reduce delays and moderate costs. 
- Executing: Excavation took place before the WaldorfAstoria Hotel, the building which was occupying the site, was completely demolished. This was part of the 'fasttrack' approach. The foundation was laid by 600 workers running in two 12-h shifts. The building applied a modular construction approach for the steel frame skeleton. The frame construction began in March 1930. The required materials were prefabricated offsite but nearby as initially planned. A key challenge was that steel beams could only be lifted 30 storeys at a time. This required the use of several hoists to get the beams to higher levels. The project workforce amounted to 3500 men who were required to work Sundays and holidays to meet the ambitious schedule.

- Monitoring and controlling: Moving bricks around using wheelbarrows was found to be inefficient and physically demanding. This was addressed by designing a chute where bricks were dumped into carts which were then lifted to the required floor. Daily work was monitored using just-in-time. This allowed the contractor to determine if the day's production was aligned with the project plans. The workforce required sustenance to maintain the intense level of work expected. Lunch counters were established on various floors to reduce travelling time for the men. This also enabled the project to run more efficiently as more time was available for lunch and production. The build rate was more than a floor a day and within 6 months, the steel frame extended 86 floors.

- Closing: The project was completed ahead of schedule and within 11 months. The project was also within budget as the total cost was approximately US $\$ 25$ million of the estimated budget of US $\$ 50$ million. The Empire State Building is still renowned as a key New York landmark and was classified as the eighth wonder of the world. The building was also the tallest building in the world until the construction of the World Trade Towers in 1972.

A multitude of projects have been embarked on over the centuries, as discussed above. Figure 1 provides a comprehensive overview of projects from 2550 BCE to 1931 AD. Some famous projects include Stonehenge, Ziggurat of Urnammu, Terra Cotta Warriors, City of Petra, Statue of Zeus at Olympia, Castillo de Loarre, Angkor Wat, the Eiffel Tower and the Golden Gate Bridge. An initial observation of the map shows that the majority of historical projects were built in the northern hemisphere and particularly modern-day Europe. Apart from the Great Pyramid of Giza, there is no formal history regarding ancient, historical projects in Africa. Interestingly, the literature argues that the famous journeys of Marco Polo and Columbus are also historical projects which realised great success (Kozak-Holland 2011). Another take on these journeys is that they resulted in colonisation and were precursors to future colonisation efforts by, for example, the British.

\section{Philosophising about project management}

The concept of project management consists of two individual concepts: project and management. The project part focuses on the technical aspects of project management. Technical

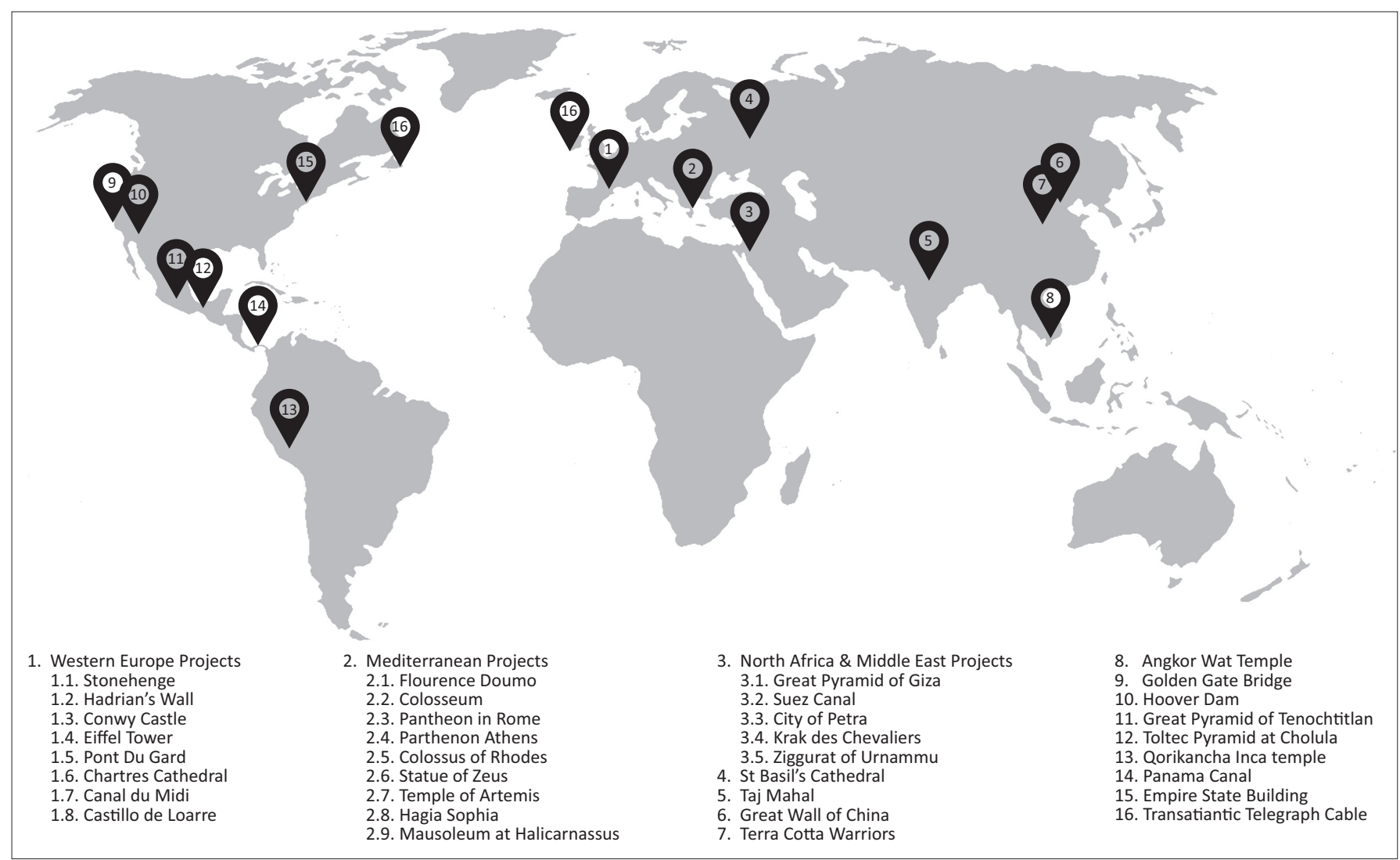

FIGURE 1: Historical map of projects. 
aspects include scheduling and requirement elicitation. The second part focuses on the management of a project. This implies that the technical aspects need to be managed in some way but most importantly that management philosophies are used to manage projects. This leads us to the question of where project management emanates from. Figure 1 indicates that projects were done in the East as well as in the West, with few or no projects in Africa or South America. This creates the impression that project management and even projects are not indigenous to Africa. Van der Merwe (2012) is of the opinion that project management emanates from two schools of thought. One is from America and the other is from Europe. The American school of thought focuses on an industrial approach, whereas the European school of thought is more of a business approach. These two schools of thought brought about standards and methodologies such as the PMBOK® Guide (Project Management Institute 2013), PRINCE2® (Office of Government Commerce 2009) and APM Body of Knowledge (Association for Project Management 2006).

On the other side of the globe, Project to maturity (P2M) (Ohara 2005) was developed by the Project Management Association of Japan. The purpose of the standard is:

to serve as a guide to assist in enterprise growth and survival in the globally competitive business and public services environment, complementing other international project management bodies of knowledge and project management competency standards. (Ohara 2005:2)

The authors of the P2M standard perceive the Western project management standards to be superior as the purpose is to complement these standards. Project to maturity is not perceived as an alternative or Eastern way of doing project management, but rather as an extension of the Western standards.

Philosophising project management is important. According to Konstantinou and Müller (2016), philosophy is needed because (1) the world as we know it is changing, (2) we do not know all the answers and (3) it is the antecedent of theory development. When we take these three points as a starting point for discussions about infusing AMP into project management, an alternative avenue is created for philosophising about the importance of AMP. Linking to these views of Konstantinou and Müller (2016), Van der Merwe (2012) mentions that projects in Africa are unsuccessful because project management theorists are unfamiliar with Africa as a continent and that they do not take this into consideration when they develop theories.

\section{African management philosophy versus Western management philosophy}

Various authors highlight the difference between WMP and AMP (Hunter 2012; Karsten \& Illa 2005; Lutz 2009; Nzelibe 1986). The fundamental difference between these contradicting philosophies is that WMP focuses on individualism, whereas AMP focuses on groups without negating the importance of the individual (Nzelibe 1986). Nzelibe states the difference as follows:
Western management thought advocates Eurocentricism, individualism, and modernity, [whereas] African management thought emphasizes ethnocentrism, traditionalism, communalism, and cooperative teamwork. (p. 11)

Western management philosophy is based on the concept of capitalism, which consists of seven basic principles, which are briefly as follows:

- Competitive markets: Within a competitive market, there are a large number of producers competing against each other to satisfy the needs of various customers. The main driving force of a competitive market is profit. It must be noted that this market is all about the winner takes all (Dew, Goldfarb \& Sarasvathy 2006). Care should be taken to prevent uncompetitive behaviour from smothering markets (National Planning Commission 2011).

- Price system: This system is a sub-component of any economic system where the valuation and distribution of goods and services are expressed as a price. Prices can be fixed or free based on the markets. The concern is that there is growing evidence that businesses are exploiting the price system for the sake of profit. South African businesses have colluded in price fixing in various sectors, for example construction, consumer goods and financial institutions.

- Voluntary exchange: This occurs when both buyers and sellers voluntarily exchange in market transactions (Adler 2015). The aim is for both parties to be better off after the exchange.

- Wage labour: This is a socio-economic relationship between a worker and an employer where the worker is paid by the employer for the work or effort being done. This relationship is also open to abuse where the worker can be exploited by the employer. This is especially the case in countries where job opportunities are scarce. The ideal situation would be where wage labour is substituted for the opportunity of self-employment (Rahman 2004).

- Capital accumulation: The capital base of a business is increased using the profits. It involves the acquisition of more assets that are used again to create more wealth. There are various examples in Africa where capital accumulation is promoted (Alon et al. 2014; Fuchs \& Horak 2008).

- Private property: This principle focuses on tangibles and intangibles owned either by individuals or by businesses over which their owners have exclusive and absolute legal rights. Private property can be transferred only with its owner's consent, and by due process such as sale or gift.

- Owner-value maximisation: This principle arises from agent theory and the thinking is that the agent should maximise the value of an owner's goods. These goods can include private property or wage labour.

These principles by themselves are fair and just. The problem is not necessarily with WMP, but there is a possibility that they promote unethical behaviour. This unethical behaviour is promoted by a person's greed and inherent tendency to exploit others. 
On the other side of the scale, we find AMP, which is founded in ubuntu (Goldman 2013). Ubuntu is seen as 'a pervasive spirit of caring and community, harmony and hospitality, respect and responsiveness, that individuals and groups display for one another' (Karsten \& Illa 2005:607). African management philosophy can be summarised as follows:

- Solidarity: This is an agreement that exists amongst individuals. These individuals will have a common interest and will feel the same about certain aspects or topics.

- Compassion: This derives from the Latin compassio which means co-suffering. Compassion implies that individuals feel for each other and thus create solidarity.

- Respect: It originates from the way that a person considers the rights of others. This implies that the rights of the colonised are just as important as those of the colonisers.

- Dignity: This principle states that there is 'value intrinsic to something about human nature that demands honouring' (Metz 2007:329).

- Humanness: Within the context of ubuntu, this implies that an individual's personality is dependent on his or her relationship with the community at large.

- Caring: Metz (2007) mentions that caring can take place at six levels, that is, conation (wishing someone well), cognition (someone is worthy of assistance), intention (one individual aims to help another individual), volition (acts to help another individual), motivation (acts for another person's sake) and affection (feeling good when someone is benefitted from our actions).

- Sharing: This is summarised by McFarlin, Coster and Mogale-Pretorius (1999:74) as 'sharing in the pleasure of profit and the disappointment of loss'.

Figure 2 provides a graphical presentation of the sometimes contrasting principles of AMP versus WMP.

The difference between AMP and WMP is that WMP can lead to unethical behaviour. Western management philosophy, as is, cannot be faulted; however, it creates the opportunity for exploitation of the workforce as well as the introduction of uncompetitive behaviour.

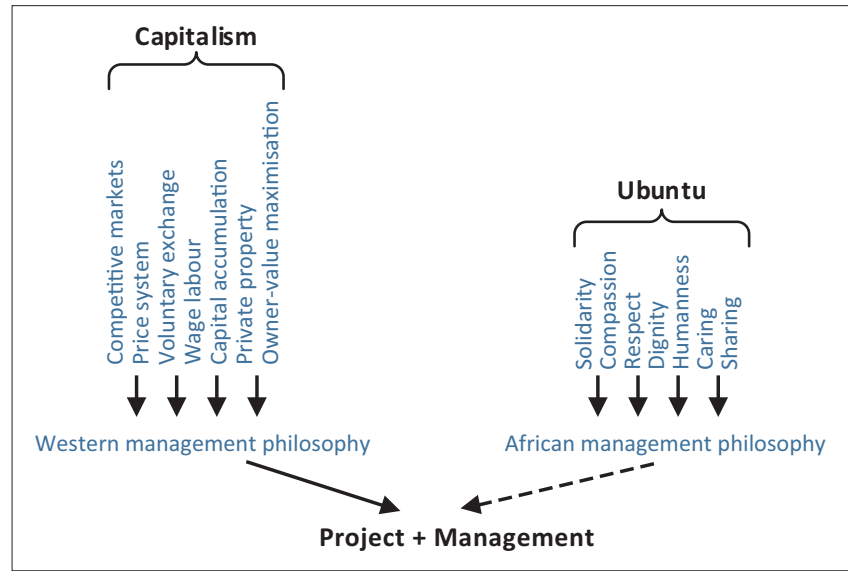

FIGURE 2: Infusing African management philosophy into project management.
Figure 1 highlighted that project management is not necessarily an African management concept and that it is practised around the globe apart from Africa south of the Sahara. It can be deduced that project management is a Western concept infused with WMP. The question is whether AMP can also be infused into project management and whether it makes sense in doing so.

A project is defined as a temporary undertaking that creates a unique product or service (Project Management Institute 2013). Project management, on the other hand, is defined as the application of knowledge, skills, tools and techniques in order to meet project requirements (Project Management Institute 2013). African management philosophy can be infused into the knowledge and skills parts of the definition. Tools and techniques are fairly technical and irrespective of the management principles followed; they will not have an impact on how these tools and techniques are applied. Tools and techniques are agnostic of management principles.

The most popular project management standard in Africa is the PMBOK® Guide. This standard consists of 10 knowledge areas comprising 47 processes. The processes that can be infused with AMP need to be identified and analysed to determine how this infusion can be done. Table 1 provides a mapping of the possible processes that may be infused with AMP. It is evident that not all the processes can be infused. Some of the processes are principle agnostic. These processes are more technical in nature and do not necessarily encompass management principles. An example is the processes under the time management knowledge area. These processes are used to create a project schedule. Irrespective of the management philosophy that is followed, activities need to be sequenced and there is only a certain way to achieve this.

Project managers should be mindful about the processes where AMP can be infused. The infusion of AMP will contribute to a more humane way of working with people where the ultimate goal is not just profits, but where the focus is commerce with morality and social well-being.

Infusing AMP as a management concept will not replace the transfer of knowledge from the Western world but 'can support the development of a hybrid management system operating in Africa within which these Western concepts can find their proper African translation' (Karsten \& Illa 2005:613). This introduces implications for business education and project management. The African voice is clearly not heard in current literature and requires extensive promotion. Zavala (2013) promotes grassroots participatory action research as a means to develop a clear understanding of what is required to decolonise the curriculum. Moreover, scholars should become 'students of the formation of grassroots organizations that are generating alternative, collective education and research projects' (Zavala 2013:68). Being participants and students will facilitate the generation of historically new interpretations and practices for infusing AMP. 
TABLE 1: Mapping of African management philosophy to Project Management Body of Knowledge Guide processes.

\begin{tabular}{|c|c|c|}
\hline Knowledge area & Processes & $\begin{array}{l}\text { Infuse African } \\
\text { management philosophy }\end{array}$ \\
\hline \multirow{6}{*}{$\begin{array}{l}\text { Integration } \\
\text { management }\end{array}$} & 1. Develop project charter & - \\
\hline & 2. Develop project management plan & - \\
\hline & 3. Direct and manage project work & $\checkmark$ \\
\hline & 4. Monitor and control project work & $v$ \\
\hline & 5. Perform integrated change control & - \\
\hline & 6. Close project or phase & - \\
\hline \multirow{6}{*}{$\begin{array}{l}\text { Scope } \\
\text { management }\end{array}$} & 1. Plan scope management & - \\
\hline & 2. Collect requirements & $\checkmark$ \\
\hline & 3. Define scope & $v$ \\
\hline & 4. Create work breakdown structure & - \\
\hline & 5. Validate scope & $\checkmark$ \\
\hline & 6. Control scope & $\checkmark$ \\
\hline \multirow{7}{*}{$\begin{array}{l}\text { Time } \\
\text { management }\end{array}$} & 1. Plan schedule management & - \\
\hline & 2. Define activities & - \\
\hline & 3. Sequence activities & - \\
\hline & 4. Estimate activity resources & - \\
\hline & 5. Estimate activity duration & - \\
\hline & 6. Develop schedule & - \\
\hline & 7. Control schedule & - \\
\hline \multirow{4}{*}{$\begin{array}{l}\text { Cost } \\
\text { management }\end{array}$} & 1. Plan cost management & - \\
\hline & 2. Estimate costs & - \\
\hline & 3. Determine budget & - \\
\hline & 4. Control costs & - \\
\hline \multirow{3}{*}{$\begin{array}{l}\text { Quality } \\
\text { management }\end{array}$} & 1. Plan quality management & - \\
\hline & 2. Perform quality assurance & - \\
\hline & 3. Control quality & - \\
\hline \multirow{4}{*}{$\begin{array}{l}\text { Resource } \\
\text { management }\end{array}$} & 1. Plan human resource management & $v$ \\
\hline & 2. Acquire project team & $\checkmark$ \\
\hline & 3. Develop project team & $v$ \\
\hline & 4. Manage project team & $v$ \\
\hline \multirow{3}{*}{$\begin{array}{l}\text { Communication } \\
\text { management }\end{array}$} & 1. Plan communication management & $\checkmark$ \\
\hline & 2. Manage communications & $\checkmark$ \\
\hline & 3. Control communications & $\checkmark$ \\
\hline \multirow{6}{*}{$\begin{array}{l}\text { Risk } \\
\text { management }\end{array}$} & 1. Plan risk management & - \\
\hline & 2. Identify risks & - \\
\hline & 3. Perform qualitative risk analysis & - \\
\hline & 4. Perform quantitative risk analysis & - \\
\hline & 5. Plan risk responses & - \\
\hline & 6. Control risks & - \\
\hline \multirow{4}{*}{$\begin{array}{l}\text { Procurement } \\
\text { management }\end{array}$} & 1. Plan procurement management & $\checkmark$ \\
\hline & 2. Conduct procurements & $\checkmark$ \\
\hline & 3. Control procurements & v \\
\hline & 4. Close procurements & $\checkmark$ \\
\hline \multirow{4}{*}{$\begin{array}{l}\text { Stakeholder } \\
\text { management }\end{array}$} & 1. Identify stakeholders & $v$ \\
\hline & 2. Plan stakeholder management & $v$ \\
\hline & 3. Manage stakeholder engagement & $\checkmark$ \\
\hline & 4. Control stakeholder engagement & $v$ \\
\hline
\end{tabular}

\section{Application to project management curriculum}

Guruba (2015) raises the point that when considering infusing AMP into a current curriculum, there are two choices. The first choice is to adopt AMP and expand on the current curriculum and the second choice is to reinvent the entire approach of thinking how the object of study itself is constituted, what tools are used to study it and what concepts are used to frame it. It was noted previously that project management is more of a Western concept and is not necessarily a concept indigenous to Africa.
This implies that the curriculum can only adopt AMP and infuse its principles into the current curriculum. How can this be done? Infusing AMP into the curriculum must be a conscientious effort from the academic staff who teach project management. This is not something that will come naturally and effort must be made to make academics aware of these principles and how they can be incorporated into project management. Firstly, academic staff must receive training on AMP and how it can be applied to the teaching of project management. Secondly, the content of prescribed textbooks must be adapted to cover aspects of AMP. This in itself creates new challenges as most project management textbooks are written by Western authors. This means that academic staff must either write textbooks with AMP as the focus or current textbooks need to be supplemented with notes on how AMP can be infused into project management. Finally, true infusion of AMP is best facilitated through the interaction between academics, students and stakeholders as each entity can provide critical input regarding decolonised curriculum development.

Relating the debate back to the three points raised by Konstantinou and Müller (2016), the world is changing and Africa as a whole is calling for recognition. This recognition is about Africa's culture, indigenous knowledge and management principles. The second point raised the notion that we do not know all the answers. This article does not claim to know all the answers but opens the debate for future discussions. Hopefully, these discussions will shed some light on the questions that require answers. The third point is that new theory needs to be created. This can only happen when we infuse AMP into project management and create new theories around the way that projects should be managed. Research into AMP and project management should be of an applied nature where the findings of basic research are exploited further to address the need to create project management theory infused with AMP.

\section{Conclusion}

Creating awareness of AMP and infusing it into the project management curriculum is a journey and quick results should not be expected. Academic staff will determine whether we practise lip service to AMP or whether we really want to infuse AMP into the academic curriculum. The ultimate test would be when current students become practitioners and display the values of AMP during project implementation.

\section{Acknowledgements Competing interests}

The authors declare that they have no financial or personal relationships that may have inappropriately influenced them in writing this article.

\section{Authors' contributions}

C.M. was responsible for the conceptualisation, literature review and drafting of the article. W.E. was responsible for 
literature review on the history of colonisation. N.J. was responsible for literature review on the history of project management.

\section{References}

Adler, P.S., 2015, 'Marxist philosophy and organization studies: Marxist contributions to the understanding of some important organizational forms', Philosophy and Organization Theory 32, 123-153.

Ahuja, D.R. \& Rajani, M.B., 2016, 'On the symmetry of the central dome of the Taj Mahal', Current Science 110(6), 996-999. https://doi.org/10.18520/cs/v110/ i6/996-999

Alon, J.C., Lattemann, C., McIntyre, J.R., Zhang, W.I., Zhang, J., Alon, I. \& Chen, Y., 2014 'Does Chinese investment affect sub-Saharan African growth?', International Journal of Emerging Markets 9(2), 257-275. https://doi.org/10.1108/IJoEM-10-2013-0171

Association for Project Management, 2006, APM body of knowledge, 5th edn., Association for Project Management, Buckinghamshire.

Association for Project Management, 2012, APM body of knowledge, Association for Project Management, Buckinghamshire.

Avery, D.R., Volpone, S.D., Stewart, R.W., Luksyte, A., Hernandez, M., McKay, P.F. et al., 2013, 'Examining the draw of diversity: How diversity climate perceptions affect job pursuit intentions', Human Resource Management 52(2), 175-193. https:// doi.org/10.1002/hrm.21524

Bailey, K., 2007, Vasco Da Gama: Quest for the spice trade, Crabtree Publishing Company, New York.

Bashford, A., 2003, Imperial hygiene: A critical history of colonialism, nationalism and public health, Springer, New York.

Bernhard, M., Reenock, C. \& Nordstrom, T., 2004, 'The legacy of Western overseas colonialism on democratic survival', International Studies Quarterly 48(1), 225250. https://doi.org/10.1111/j.0020-8833.2004.00298.x

Berry, S., 1989, 'Social institutions and access to resources', Africa 59(1), 41-55. https://doi.org/10.2307/1160762

Broodryk, J., 2002, Ubuntu: Life lessons from Africa, Ubuntu School of Philosophy, Bloomington, IN.

Charles, M.A., 1930, 'Hagia Sophia and the great imperial mosques', The Art Bulletin 12(4), 321-344. https://doi.org/10.1080/00043079.1930.11409287

CHE, 2017, Decolonising the curriculum: Stimulating debate, Pretoria, South Africa, viewed from http://www.che.ac.za/sites/default/files/publications/BrieflySpeaking $\% 20$ $\% 283 \% 29 \% 20$ Curriculum $\% 20$ decolonisation.pdf

Chidester, D., 1996, Savage systems: Colonialism and comparative religion in Southern Africa, University of Virginia Press, Charlottesville, VA.

Comaroff, J., 2013, Body of power, spirit of resistance: The culture and history of a South African people, University of Chicago Press, Chicago, IL.

Conniff, M.L. \& Davis, T.J., 2004, 'Africans in the Americas: A history of the Black diaspora', in Perspectives in history, p. 101, Blackburn Press, Caldwell,

Cook, M., 2016, Personnel selection: Adding value through people - A changing picture, John Wiley \& Sons, Hoboken.

Da Silva, F.R., 2011, Dutch and Portuguese in Western Africa: Empires, merchants and the Atlantic system, 1580-1674, Brill, Hoboken.

Daughton, J.P., 2006, An empire divided: Religion, republicanism, and the making of French colonialism, 1880-1914, Oxford University Press, Oxford.

Dew, N., Goldfarb, B. \& Sarasvathy, S., 2006, 'Optimal inertia: When organizations should fail', Ecology and Strategy 23, 73-99.

Dunleavy, P., 2014, Democracy, bureaucracy and public choice: Economic approaches in political science, Routledge, Abingdon.

Dunnett, D., 1983, 'Self-determination and the Falklands', International Affairs (Roya Institute of International Affairs 1944 59(3), 415-428. https://doi.org/10.2307/ 2618795

Eckert, A., 2004, 'Regulating the social: Social security, social welfare and the state in late colonial Tanzania', The Journal of African History 45(3), 467-489. https://doi. org/10.1017/S0021853704009880

Edwards, J.F., 2003, 'Building the Great Pyramid: Probable construction methods employed at Giza', Technology and Culture 44(2), 340-354. https://doi. org/10.1353/tech.2003.0063

Erasmus, L.J., 2008, The management of workforce diversity and implications for leadership at financial asset services, University of Johannesburg, Johannesburg.

Flood, R.L. \& Romm, N.R.A., 1996, Diversity management: Triple loop learning, Wiley \& Sons, Hoboken, NJ.

Fuchs, C. \& Horak, E., 2008, 'Africa and the digital divide', Telematics and Informatics 25(2), 99-116. https://doi.org/10.1016/j.tele.2006.06.004

Goldman, G.A., 2013, 'On the development of uniquely African management theory', Indilinga African Journal of Indigenous Knowledge Systems 12(2), 217-230.

Grier, R.M., 1999, 'Colonial legacies and economic growth', Public Choice 98(3-4), 317-335. https://doi.org/10.1023/A:1018322908007

Griffiths, P.J., 2013, 'The natural right to property and the impossibility of owning the intangible: A tension in Catholic thought 1', University of St. Thomas Law Journal 10, 590-1123.

Guruba, H., 2015, 'What is an African curriculum?', Mail \& Guardian, viewed 03 April 2017, from http://mg.co.za/article/2015-04-17-what-is-an-african-curriculum
Hamilton, R., 2016, 'South Africa: Fees must fall', Advocate: Newsletter of the National Tertiary Education Union 23(3), 43.

Heleta, S., 2016, 'Decolonisation of higher education: Dismantling epistemic violence and Eurocentrism in South Africa', Transformation in Higher Education 1(1), 1-8. https://doi.org/10.4102/the.v1i1.9

Henderson, R., 2016, Scrap science, start over: The frightening call of a fallist, viewed 23 April 2017, from http://www.businesslive.co.za/news/latest-news/2016-1014-scrap-science-start-over-the-frightening-call-of-a-fallist/

Henn, A., 2014, Hindu-Catholic encounters in Goa: Religion, colonialism, and modernity, Indiana University Press, Bloomington, IN.

Heugh, K., 2015a, 'Cost implications of the provision of mother-tongue and strong bilingual models of education in Africa. A review and analysis of theory and practice in mother-tongue and bilingual education in sub-Saharan Africa', in A Ouane \& G. Glanz (eds.), Optimising learning, education and publishing in Africa: The language factor, pp. 255-289, African Development Bank, Hamburg.

Heugh, K., 2015b, 'Mother-tongue education is best', Human Sciences Research Council Journal 3(3), 8-9.

Higgs, P., 2012, 'African philosophy and the decolonisation of education in Africa: Some critical reflections', Educational Philosophy and Theory 44(suppl. 2), 37-55. https://doi.org/10.1111/j.1469-5812.2011.00794.x

Hunter, M., 2012, The dominance of 'Western' management theories in South-East Asian business schools: The Occidental colonization of the mind, viewed 13 March 2017, from http://www.4thmedia.org/2012/08/the-dominance-of-western-managementtheories-in-south-east-asian-business-schools-the-occidental-colonization-of-the-mind/

Huntington, S.P., 2000, 'The clash of civilizations?', in Crothers L., Lockhart C. (eds.), Culture and Politics, pp. 99-118. Palgrave Macmillan, New York. https://doi. org/10.1007/978-1-349-62397-6 6

Ioannidis, J.P., 2012, 'Why science is not necessarily self-correcting', Perspectives on Psychological Science 7(6), 645-654. https://doi.org/10.1177/1745691612464056

Jackson, T., 2004, 'Africa and international management: Why bother', AlB Insights $4(1), 6-8$.

Janse van Rensburg, A., 2016 (01 June), 'Leerlinge verstaan nie wat hulle lees nie', Beeld, viewed 02 February 2017, from https://www.netwerk24.com/Nuus/ Onderwys/groot-gros-leerlinge-verstaan-nie-wat-hulle-lees-20160601

Jeffreys, M., 1953, 'The history of Maize in Africa', The Eastern Anthropologist 7(1), 138-148.

Jiggins, J., 1989, 'An examination of the impact of colonialism in establishing negative values and attitudes towards indigenous agricultural knowledge', in D.M. Warren, L.J. Slikkerveer \& S.O. Titilola (eds.), Indigenous knowledge systems: Implications for agriculture and international development, lowa State University Research Foundation, Ames, IA.

Joireman, S.F., 2001, 'Inherited legal systems and effective rule of law: Africa and the colonial legacy', The Journal of Modern African Studies 39(4), 571-596. https:// doi.org/10.1017/S0022278X01003755

Karsten, L. \& IIla, H., 2005, 'Ubuntu as a key African management concept: Contextual background and practical insights for knowledge application', Journal of Managerial Psychology 20(7), 607-620. https://doi.org/10.1108/02683940510623416

Kaunda, C., 2016, 'The wilderness wanderings: A theo-liminal pedagogy for mind decolonisation in African Christianity', Acta Theologica 36(1), 52-69. https://doi. org/10.4314/actat.v36i1.4

Konstantinou, E. \& Müller, R., 2016, 'The role of philosophy in project management', Project Management Journal 47(3), 3-11.

Kozak-Holland, M., 2011, The history of project management, Multi-Media, Ontario

Kwong, M., Au, K., Poon, A., Lau, P. \& Loh, E., 2014, 'Exploring tiered assessment: Catering for differences between learners in Hong Kong Multiethnic Chinese Language Classroom', Paper presented at the International Association for the Improvement of Mother Tongue Education (IAIMTE) Small Interest Group (SIG) Conference, Brussels.

Leonard, T.M., 2005, Encyclopedia of the developing world, Routledge, Abingdon. Lilly, A., 2008, Spanish colonies in America, Compass Point Books, North Mankato

Lovejoy, P.E., 2011, Transformations in slavery: A history of slavery in Africa, vol. 117, Cambridge University Press, Cambridge

Lutz, D.W., 2009, 'African ubuntu philosophy and global management', Journal of Business Ethics 84(3), 313. https://doi.org/10.1007/s10551-009-0204-z

Mackenzie, P., 2013, 'Mother tongue-based multilingual education as a key to access and quality', English Language Teacher Education in a Diverse Environment 194-201.

Malhotra, B., 2014, 'Foreign direct investment: Impact on Indian economy', Global Journal of Business Management and Information Technology 4(1), 17-23.

Maserumule, M.H., 2015, Why Africa's professors are afraid of colonial education being dismantled, viewed from https://mg.co.za/article/2015-11-26-why-africasbeing dismantled, viewed from $\mathrm{https}: / / \mathrm{mg}$.co.za/article/2015-11
professors-are-afraid-of-colonial-education-being-dismantled

Matthew, M.M., 2013, 'Repurposing and legacy of innovation', in M.M. Mars \& S. Hoskinson (eds.), A cross-disciplinary primer on the meaning and principles of innovation, vol. 23, pp. 51-63, Emerald Group.

McComas, W.F., 2004, 'The nature of science', The Science Teacher 71(9), 24-27.

McFarlin, D.B., Coster, E.A. \& Mogale-Pretorius, C., 1999, 'South African management development in the twenty-first century: Moving toward an Africanized model', Journal of Management Development 18(1), 63-78. https://doi.org/10.1108/ 02621719910250474

McLaughlin, J. \& Whatman, S., 2011, 'The potential of critical race theory in decolonizing university curricula', Asia Pacific Journal of Education 31(4), 365-377. https://doi.org/10.1080/02188791.2011.621243 
Merryfield, M.M., 2000, 'Why aren't teachers being prepared to teach for diversity, equity, and global interconnectedness? A study of lived experiences in the making
of multicultural and global educators', Teaching and Teacher Education 16(4), 429-443. https://doi.org/10.1016/S0742-051X(00)00004-4

Metz, T., 2007, 'Toward an African moral theory', Journal of Political Philosophy 15(3), 321-341. https://doi.org/10.1111/j.1467-9760.2007.00280.x

Middleton, R. \& Lombard, A., 2011, Colonial America: A history to 1763, Wiley and Sons, Hoboken

Mignolo, W., 2012, Local histories/global designs: Coloniality, subaltern knowledges, and border thinking, Princeton University Press, Princeton, NJ.

Miracle, M.P., 1965, 'The introduction and spread of maize in Africa', The Journal of African History 6(1), 39-55. https://doi.org/10.1017/\$0021853700005326

Mudimbe, V.Y., 1985, 'African Gnosis Philosophy and the order of knowledge: An introduction', African Studies Review 28(2/3), 149-233. https://doi.org/ $10.2307 / 524605$

Myers, R.H., Peattie, M.R., Zhen, J. \& Studies, J.C.O.J., 1984, The Japanese colonial empire, 1895-1945, Princeton University Press, Princeton, NJ.

National Planning Commission, 2011, National Development Plan 2030. Our future make it work, viewed from http://www.poa.gov.za/news/Documents/NPC $\% 20$ National\%20Development $\% 20$ Plan\%20Vision $\% 202030 \% 20$-lo-res.pdf

Newitt, M.D.D., 1986, The first Portuguese colonial empire, University of Exeter Exeter.

Nunn, N., 2008, 'Slavery, inequality, and economic development in the Americas', Institutions and Economic Performance 15, 148-180.

Nunn, N. \& Qian, N., 2010, 'The Columbian exchange: A history of disease, food, and ideas', The Journal of Economic Perspectives 24(2), 163-188. https://doi. org/10.1257/jep.24.2.163

Nzelibe, C.O., 1986, 'The evolution of African management thought', Internationa Studies of Management \& Organization 16(2), 6-16. https://doi.org/10.1080/002 08825.1986 .11656427

Office of Government Commerce, 2009, Managing successful projects with PRINCE2 5 th edn., The Stationary Office, London.

Ohara, S., 2005, P2M: A guidebook of project \& program management for enterprise innovation, 3rd edn., Project Management Association of Japan, Tokyo.

Pakenham, T., 2015, The scramble For Africa, Little Brown Book Group, Boston, MA.

Parsons, T., 2004, Race, resistance, and the Boy Scout movement in British Colonial Africa, Ohio University Press, Athens.

Pillay, S., 2015, Decolonizing the university, viewed 02 April 2017, from http:// africasacountry.com/2015/06/decolonizing-the-university/

Poirier, R. \& Ostergren, D., 2002, 'Evicting people from nature: Indigenous land rights and national parks in Australia, Russia, and the United States', Natural Resources Journal 42, 331.

Porter, A. \& Louis, W.R., 2001, The Oxford history of the British Empire: Volume III: The nineteenth century, OUP, Oxford

Project Management Institute, 2013, A guide to the Project Management Body of Knowledge (PMBOK Guide), 5th edn., Newtown Square, PA.
Rahman, A., 2004, 'Globalization: The emerging ideology in the popular protests and grassroots action research', Action Research 2(1), 9-23. https://doi.org/ 10.1177/1476750304040495

Ramoupi, N.L.L., 2015, 'The African vision has lost its focus', Mail \& Guardian, viewed 07 April 2017, from http://mg.co.za/article/2015-02-06-the-african-vision-haslost-its-focus

Smith, L.T., 1999, Decolonizing methodologies: Research and indigenous peoples, Zed Books, London.

Stevenson, A., 2010, Oxford dictionary of English, Oxford University Press.

Thiong'o, N., 1994, Decolonising the mind: The politics of language in African literature, East African Educational Publishers, Nairobi.

Ting-Toomey, S., Yee-Jung, K.K., Shapiro, R.B., Garcia, W., Wright, T.J. \& Oetzel, J.G., 2000, 'Ethnic/cultural identity salience and conflict styles in four US ethnic groups', International Journal of Intercultural Relations 24(1), 47-81. https://doi. groups', International Journal of Intercuh

Todd, Z., 2016, 'An indigenous feminist's take on the ontological turn: "Ontology" is just another word for colonialism', Journal of Historical Sociology 29(1), 4-22. https://doi.org/10.1111/johs.12124

Tuck, E. \& Yang, K.W., 2012, 'Decolonization is not a metaphor', Decolonization: Indigeneity, Education \& Society 1(1), 1-40.

Turshen, M., 1977, 'The impact of colonialism on health and health services in Tanzania', International Journal of Health Services 7(1), 7-35. https://doi. org/10.2190/L9G4-KJVK-AW7A-Q9JD

United Nations General Assembly \& United Nations Office of Public Information, 1974 , Declaration on the granting of independence to colonial countries and peoples, United Nations Office of Public Information, New York.

Van der Merwe, A.P., 2012, 'Project management philosophy: Incremental improvement of project management through the use of research', PM World Journal 1(3), 1-17.

Walton, G.M. \& Rockoff, H., 2013, History of the American economy, Cengage Learning, Boston, MA.

Webster, 2016, The Merriam-Webster dictionary, Merriam-Webster, Springfield.

Wigoder, M., 2002, 'The "solar eye" of vision: Emergence of the skyscraper-viewer in the discourse on heights in New York City 1890-1920', Journal of the Society of Architectural Historians 61(2), 152-169. https://doi.org/10.2307/991837

Wingfield, B., 2017, What 'decolonised education' should and shouldn't mean, viewed 23 March 2017, from https://theconversation.com/what-decolonised-educationshould-and-shouldnt-mean-72597

Wolfe, P. \& Mikdashi, M., 2013, 'What is settler colonialism? (for Leo Delano Ames Jr.)', American Indian Culture and Research Journal 37(2), 23-34. https://doi. org/10.17953/aicr.37.2.c33g723731073714

Zavala, M., 2013, 'What do we mean by decolonizing research strategies? Lessons from decolonizing, Indigenous research projects in New Zealand and Latin America', Decolonization: Indigeneity, Education \& Society 2(1), 55-71

Zoogah, D.B., Peng, M.W. \& Woldu, H., 2015, 'Institutions, resources, and organizational effectiveness in Africa', The Academy of Management Perspectives 29(1), 7-31. https://doi.org/10.5465/amp.2012.0033 